\title{
Draining the Sea with Discretion: \\ Force Integration and Civilian Displacement during South Korean Counter-insurgency Operations, 1948-1953
}

\author{
Seung Joon Paik \\ Peace and Democracy Institute \\ Korea University \\ 145 Anam-ro, Seongbuk-gu \\ Seoul, South Korea \\ sjoonpaik@gmail.com \\ ORCID: 0000-0002-7729-6167 \\ Soul Park \\ Department of Political Science \\ National University of Singapore \\ AS1, \#04-39, 11 Arts Link \\ Singapore 117570 \\ polsp@nus.edu.sg \\ ORCID: 0000-0001-6692-9080
}

\begin{abstract}
This paper analyses the dynamics of violence during civilian displacement operations. Specifically, we argue that the integration of security forces - solid command structure, monitoring of troops, and the quality of personnel - influences not only the military performance but also the level of civilian costs. That is, a highly integrated army can commit soldiers to displacement operations while minimising violence. When conducted by a partially integrated army, however, displacement operations are at risk of mass killing, pushing soldiers to remove civilians without sophisticated control. Our qualitative analysis of three major counter-guerrilla operations in South Korea provides support for our thesis.
\end{abstract}

KEYWORDS Korean counter-insurgency (COIN); draining-the-sea tactic; civilian displacement; principal-agent problem; internal cohesion

ACKNOWLEDGEMENT The authors would like to thank Chonghyun Choi, Col. Bryan Gibby, Yoav Gortzak, Stathis Kalyvas, Inwook Kim, Barnett Koven, Jason Lyall, Kimberly Peh, Samuel Plapinger, Subhasish Ray, participants at Yale University's Program on Order, Conflict, and Violence workshop, the editors and the two anonymous reviewers for their productive comments and constructive criticisms.

\section{Accepted}

Journal of Strategic Studies

October 3, 2020 


\section{Introduction}

What explains the variations in military outcomes and the magnitude of civilian costs during civilian displacement operations? Although forceful displacement (or relocation) of civilians has been prohibited by international humanitarian law in the post-World War II era, the tactic has continuously been employed as an integral counter-insurgency (COIN) measure, as it is widely believed to be effective in cutting off insurgent support. ${ }^{1}$ According to a survey of COIN operations between 1945 and 2000, it was employed in 22 out of the 47 cases observed. ${ }^{2}$

Despite its widespread use, civilian displacement tactic has yet to receive a thorough treatment within the existing literature. Not until recently have scholars started to distinguish the notion of civilian displacement from mass killing, as the concepts have often been discussed interchangeably within the broad term of 'draining the sea' ${ }^{3}$ Moreover, studies that consider displacement a distinct type of violence have not analyzed the varying level of civilian costs in such operations, assuming the tactic to be inherently violent. ${ }^{4}$ Yet, civilian displacement does not necessarily entail extreme brutality and the outcome has historically been mixed. To better forecast and reduce civilian casualties during low-intensity conflicts, it is imperative to analyze the conditions under which displacement operations are conducted less violently while denying insurgent support.

\footnotetext{
${ }^{1}$ Yuri Zhukov, 'Population Resettlement in War: Theory and Evidence from Soviet Archives', Journal of Conflict Resolution, 59/7 (2015), 1156-7.

${ }^{2}$ Stephen Pampinella, 'The Effectiveness of Coercive and Persuasive Counterinsurgency Practices since 1945', Civil Wars, 17/4 (2015), 503-26.

${ }^{3}$ Alexander Downes, 'Draining the Sea by Filling the Graves: Investigating the Effectiveness of Indiscriminate Violence as a Counterinsurgency Strategy', Civil Wars, 9/4 (2007), 420-44; and Benjamin Valentino, Paul Huth, and Dylan Balch-Lindsay, "Draining the Sea': Mass Killing and Guerrilla Warfare', International Organization, 58/2 (2004), 375-407.

${ }^{4}$ Kelly Greenhill, Weapons of Mass Migration: Forced Displacement, Coercion, and Foreign Policy (Ithaca: Cornell University Press, 2010); Abbey Steele, 'Electing Displacement: Political Cleansing in Apartadó, Colombia', Journal of Conflict Resolution, 55/3 (2011), 423-45; and Zhukov, 'Population Resettlement in War'.
} 
Here, we focus on the organisational characteristics of COIN forces, namely, force integration, to explain the military outcomes and civilian costs of displacement operations. For a government whose aims are to restore internal stability and garner legitimacy, an operation is most successful when it cuts insurgent supplies while minimising civilian victimisation. However, soldiers do not necessarily abide by this goal due to the principal-agent problem within military organisations. We argue that a stable and durable command structure, the close supervision of forces, and the quality of personnel are the key factors that promote an integrated use of force and ultimately result in a militarily successful but less violent operation.

The relationship between force integration and the outcome of displacement operations, however, is not simply linear. From the military vantage point, an improvement in force integration is highly likely to result in success, as tighter control by commanders better motivates soldiers to pursue military goals, i.e. the removal of civilians from insurgent areas. In terms of civilian costs, however, moderately integrated forces can cause greater damage than poorly integrated ones. While soldiers in the latter may victimise civilians mostly for small-scale exploitative motives, those in the former, who are more motivated to achieve the strategic goals, can be incentivised to perpetrate mass killing as an "easy" way to carry out the operation. This risk of perpetrating mass killing is only reduced when an army is highly integrated and is therefore able to regulate the use of violence meticulously.

To evaluate our theory, three case studies of major counter-guerrilla operations conducted by the newly-independent South Korean government against communist guerrillas (1948-1953) are analyzed. Utilising a wealth of primary documents produced by government forces and guerrillas, oral history records, and truth commission reports, we examine the relationship 
between the level of integration of the Korean security forces, and the magnitude of damage inflicted on the guerrillas and civilians during relocation operations.

The remainder of this paper is organised as follows. The next section presents our argument on force integration during displacement operations. In the following sections, we examine three operations before and during the Korean War: the Jeju Island Uprising (Phases 1 and 2), and operations by the Eleventh Division and Task Force Paik in Chiri Mountain. The broader scholarly and policy-relevant implications are discussed in the concluding section.

\section{Force Integration in Civilian Displacement}

'Draining the sea' has been widely employed as a key COIN tactic. When faced with internal threats, a victory by military means alone is difficult to achieve since it is challenging to gather information on insurgents, who remain nearly indistinguishable from noncombatants. ${ }^{5}$ Thus, states often simultaneously focus on civilians, a visible target, and relocate them away from insurgent-active zones to undermine the enemy's capabilities. ${ }^{6}$ Operating without their own means of production, insurgents lose significant capabilities when separated from civilians. In other words, this tactic aims to drain the 'sea' to catch the 'fish'?

While both civilian displacement and mass killing have been broadly termed 'draining the sea', as both measures serve to eliminate the entire population from an area, ${ }^{8}$ recent studies have

\footnotetext{
${ }^{5}$ Ivan Arreguín-Toft, 'How the Weak Win Wars: A Theory of Asymmetric Conflict', International Security, 26/1 (2001), 93-128; Stathis Kalyvas, The Logic of Violence in Civil War (New York: Cambridge University Press, 2006); and Jason Lyall and Isaiah Wilson, 'Rage Against the Machines: Explaining Outcomes in Counterinsurgency Wars', International Organization, 63/1 (2009), 67-106.

${ }^{6}$ Jacqueline Hazelton, 'The "Hearts and Minds" Fallacy: Violence, Coercion, and Success in Counterinsurgency Warfare', International Security, 42/1 (2017), 89-91; Steele, 'Electing Displacement'; and Zhukov, 'Population Resettlement in War'.

${ }^{7}$ Mao Zedong, On Guerrilla Warfare (Courier Corporation, 2005).

${ }^{8}$ Downes, 'Draining the Sea by Filling the Graves'; and Valentino, Huth and Balch-Lindsay, 'Draining the Sea'.
} 
started to treat displacement as a distinct type of political violence. Scholars point out that displacement tactics are more likely to be utilised when distinguishing rebels from the population is difficult or when civilians are deemed insurgent supporters. ${ }^{9}$ Little is known, however, regarding the effectiveness of the tactic itself. Although some studies demonstrate the military utility of displacement tactics, ${ }^{10}$ few systematically analyze the conditions under which the displacement tactic can be more effective. ${ }^{11}$

Furthermore, by conceptualising the tactic as being inherently violent, the literature does not address the variance in civilian costs. The tactic is indeed violent since it entails coercing civilians to relocate away from conflict zones. Yet, as demonstrated during British COIN operations in Kenya and Malaya, the same tactic can result in different degrees of civilian casualties. $^{12}$

Lastly, most studies on civilian displacement exclusively focus on the strategic function of violence; based on the rationalist and unitary actor framework, the use of violence in civilian displacement operations is assumed to be fully dedicated towards undermining insurgent support. ${ }^{13}$ That is, all instances of violence perpetrated during displacement operations are assumed to be consistent with the state's aims. Although parsimonious, such assumptions are not

\footnotetext{
${ }^{9}$ Kelly Greenhill, 'Strategic Engineered Migration as a Weapon of War', Civil Wars, 10/1 (2008), 6-21; Greenhill, Weapons of Mass Migration; Steele, 'Electing Displacement'; Abbey Steele, Democracy and Displacement in Colombia's Civil War (Ithaca: Cornell University Press, 2017); and Zhukov, 'Population Resettlement in War'.

${ }^{10}$ Alexander Downes, Targeting Civilians in War (Ithaca: Cornell University Press, 2008), ch.5.

${ }^{11}$ Zhukov concludes that large-scale displacement is more effective than smaller ones. Zhukov, 'Population Resettlement in War', 1173.

${ }^{12}$ Karl Hack, 'The Malayan Emergency as Counter-Insurgency Paradigm', Journal of Strategic Studies, 32/3 (2009), 412.

${ }^{13}$ Downes, 'Draining the Sea by Filling the Graves'; Greenhill, Weapons of Mass Migration; Steele, 'Electing Displacement'; and Zhukov, 'Population Resettlement in War'.
} 
necessarily valid during internal conflicts, in which governments have a tenuous hold of the state apparatus, including the military organisation. ${ }^{14}$

An alternative approach that can address this unexplored dimension is the principal-agent framework. By relaxing the unitary actor assumption, recent works have concentrated on the internal aspect of military organisations - including ideological commitment, social bonds, and discipline - to explain the use of violence that is inconsistent with the rational objectives of states. $^{15}$ Thus far, however, no systematic endeavor has been devoted to applying this framework to the use of violence in civilian displacement operations.

Here, we adopt the principal-agent framework to explain both military outcomes and civilian costs during displacement operations. Our theory focuses on the different incentive structures facing state leaders and high-level commanders (principals), and the junior officers and soldiers (agents). When employing draining-the-sea tactics, the principal's primary aim is to undermine insurgent support by relocating civilians from their access. At the same time, the principals also have incentives to minimise the use of violence since high civilian casualties come with the risk of losing domestic and international reputation, and potential outside intervention. ${ }^{16}$ Moreover,

\footnotetext{
${ }^{14}$ Hanne Fjelde and Indra De Soysa, 'Coercion, Co-Optation, or Cooperation? State Capacity and the Risk of Civil War, 1961-2004', Conflict Management and Peace Science, 26/1 (2009), 5-25.

${ }^{15}$ Dara Kay Cohen, 'Explaining Rape during Civil War: Cross-National Evidence (1980-2009)', American Political Science Review, 107/3 (2013), 461-77; Amelia Hoover Green, 'The Commander's Dilemma: Creating and Controlling Armed Group Violence', Journal of Peace Research, 53/5 (2016), 619-32; Devorah Manekin, 'The Limits of Socialization and the Underproduction of Military Violence: Evidence from the IDF', Journal of Peace Research, 54/5 (2017), 606-19; and Kai Thaler, 'Ideology and Violence in Civil Wars: Theory and Evidence from Mozambique and Angola', Civil Wars, 14/4 (2012), 546-67.

${ }^{16}$ Steele, 'Electing Displacement', 46-47. Consistent with our logic, recent studies indicate that civilian damage inflicted by COIN forces undermine government support while increasing insurgent backing. Luke Condra and Jacob Shapiro, 'Who Takes the Blame? The Strategic Effects of Collateral Damage', American Journal of Political Science, 56/1 (2012), 167-87; and Jason Lyall, Graeme Blair and Kosuke Imai, 'Explaining Support for Combatants during Wartime: A Survey Experiment in Afghanistan', American Political Science Review, 107/4 (2013), 679-705.
} 
unless state leaders have a genocidal aim, committing large-scale violence undermines the government's long-term interests since civilians are sources of tax, manpower, and sovereignty. ${ }^{17}$

While the principal's aim is to relocate civilians with minimal casualties, troops on the battleground often operate with different incentives. On one hand, factors such as fear of or sympathy for the insurgents and psychological unpreparedness to utilise violence can make soldiers avoid orders. ${ }^{18}$ On the other hand, soldiers may perpetrate unauthorised violence for self-serving reasons, including material and sexual benefits. ${ }^{19}$ Thus, civilian displacement operations can either fail to achieve its military goal or cause arbitrary civilian casualties when lower-level units do not closely align with the overall aims of the operation.

Given the rifts between principals and agents, government forces are less likely to achieve optimal outcomes without a considerable organisational capacity. We argue that the outcome of relocation operations is influenced by the level of integration of government forces (or force integration). ${ }^{20}$ We specifically concentrate on three attributes: the stability and durability of the command structure; monitoring efforts by commanding officers; and the quality of personnel.

First, command structure refers to the unity and durability of the command upon which all members of an army organisation agree. ${ }^{21}$ Without a clearly defined chain of command, different actors inside the establishment can undermine the unity of effort, as each have incentives to push

\footnotetext{
${ }^{17}$ Mancur Olson, 'Dictatorship, Democracy, and Development', American Political Science Review, 87/3 (1993), 567-76.

${ }^{18}$ Dave Grossman, On Killing: The Psychological Cost of Learning to Kill in War and Society (New York: Back Bay, 1995).

${ }^{19}$ John Mueller, 'The Banality of "Ethnic War”, International Security, 25/1 (2000), 42-70.

${ }^{20}$ Integration is defined as a capability of an army that ensures consistent military activity across ranks. We specifically focus on the operational and tactical level of integration. Risa Brooks, 'Introduction: The Impact of Culture, Society, Institutions, and International Forces on Military Effectiveness', in Risa Brooks and Elizabeth Stanley (eds.), Creating Military Power: The Sources of Military Effectiveness (Stanford: Stanford University Press, 2007), 10; and Allan Millett, Williamson Murray and Kenneth Watman, 'The Effectiveness of Military Organizations', International Security, 11/1 (1986), 37-71.

${ }^{21}$ Steven Metz and Raymond Millen, Insurgency and Counterinsurgency in the 21st Century: Reconceptualizing Threat and Response (Carlisle: Army War College, 2004), 32-3.
} 
costs toward the other while claiming credit for successes. ${ }^{22}$ Meanwhile, durability enables commanding officers to establish full control over their lower-level units by building relationships. That is, soldiers are more incentivised to follow orders from a long-tenured commander, considering their future interactions with their superior. ${ }^{23}$

Second, monitoring (or information management) refers to efforts made by commanders to supervise their lower-level units in action. ${ }^{24}$ Information asymmetry exists between commanders and soldiers, as operations are mostly conducted out of view of the former. Taking advantage of this, the rank and file may refuse to bear the costs of the operation (i.e., avoid engaging in battle) or seek to gain arbitrary benefits (i.e., looting civilians or colluding with the enemy). Such unauthorised actions can be controlled by commanders' efforts to maintain communication with their units during operations via messengers, radio, and GPS devices.

Third, the quality of personnel covers intangible aspects of military organisations, such as loyalty, morale, and proficient use of weapons, that contribute to a coherent operation. ${ }^{25}$ Relevant factors are recruitment, and training and combat experience. An army's capability to operate as a coherent group is affected by its recruitment process, particularly its ability to weed out incompetent or disloyal soldiers. ${ }^{26}$ In addition, training regimens contribute to cohesiveness

\footnotetext{
${ }^{22}$ Kristin Bakke, Kathleen Gallagher Cunningham and Lee Seymour, 'A Plague of Initials: Fragmentation, Cohesion, and Infighting in Civil Wars', Perspectives on Politics, 10/2 (2012), 265-83; Brooks, 'Introduction', 21-2; Kenneth Pollack, Arabs at War: Military Effectiveness, 1948-1991 (Lincoln: University of Nebraska Press, 2002), 46; and Caitlin Talmadge, The Dictator's Army: Battlefield Effectiveness in Authoritarian Regimes (Ithaca: Cornell University Press, 2015), 14.

${ }^{23}$ Robert Axelrod and William Hamilton, 'The Evolution of Cooperation', Science, 211/4489 (1981), 1390-6.

${ }^{24}$ Talmadge, The Dictator's Army, 14.

${ }^{25}$ Anthony King, The Combat Soldier: Infantry Tactics and Cohesion in the Twentieth and Twentieth-First Centuries (Oxford: Oxford University Press, 2013), 266-300; Talmadge, The Dictator's Army, 13-4; Joseph Felter, 'Sources of Military Effectiveness in Counterinsurgency: Evidence from the Philippines', in Dan Reiter (ed.), The Sword's Other Edge: Trade-offs in the Pursuit of Military Effectiveness (Cambridge: Cambridge University Press, 2017), 134; and Pollack, Arabs at War, 9.

${ }^{26}$ Paul Gill and John Horgan, 'Who Were the Volunteers? The Shifting Sociological and Operational Profile of 1240 Provisional Irish Republican Army Members', Terrorism and Political Violence, 25/3 (2013), 435-56;
} 
by preparing the recruits technically and psychologically to use violence as well as by socialising individual soldiers into their units. ${ }^{27}$ Alternatively, soldiers can also develop their proficiency through actual battle experience. In a nutshell, well-selected and trained (or experienced) soldiers are more capable and willing to conduct operations as directed.

Putting it together, variations in force integration can lead to one of three outcomes during relocation operations. First, when force integration is lacking (LOW), relocation operations are likely to result in military failure and unsystematic civilian casualties. With low organisational capacity, it is challenging for commanders to be updated on the most basic information, such as troop movement and after-action results. Without any meaningful control from above, soldiers are likely to ignore operational orders to avoid the risk of guerrilla counterattacks and instead engage in arbitrary activities. Civilians near operation areas thus become vulnerable to violence by soldiers with exploitative aims. However, the scale of civilian casualties is unlikely to escalate into systematic killing, defined as an act or attempt to eliminate the entire population in a given location. This is because violence here is driven by individual motives that are not necessarily strongly shared by all soldiers to commit murder.

Next, when there is an intermediate level of force integration (MEDIUM), a relocation operation is likely to be militarily successful but with systematic, large-scale civilian casualties. Commanders can observe and assess troop movement and operational outcomes but still lack the sophisticated capabilities needed to manage the process of operations in detail. Knowing that the outcome of the operation will later be evaluated by the commanders, soldiers are better

Thomas Hegghammer, 'The Recruiter's Dilemma: Signaling and Rebel Recruitment Tactics', Journal of Peace Research, 50/1 (2013), 3-16; and Macartan Humphreys and Jeremy Weinstein, 'Handling and Manhandling Civilians in Civil War', American Political Science Review, 100/3 (2006), 429-47.

${ }^{27}$ Grossman, On Killing, 251-63; and Hew Strachan, 'Training, Morale and Modern War', Journal of Contemporary History, 41/2 (2006), 211-27. 
incentivised to remove civilians from the target area. Given the considerable power gap between the security forces and civilians, the elimination of the civilian population per se can be easily achieved.

During the process, however, civilians are more likely to fall prey to mass killing. The very nature of uprooting civilians creates more opportunities for violence, as coercive measures are often employed. Furthermore, given the costs associated with civilian relocation (i.e., logistical and transportation costs and vulnerability to potential guerrilla attacks), junior officers and soldiers, even those without exploitative aims, can develop new situation-induced incentives to target as a 'quick and safer' way to accomplish the order. Others, driven by predatory aims, can take advantage of this violent situation. That is, while violence by a low-integrated army is mostly driven by personal motives alone, civilian victimisation by a moderately integrated military is motivated by both strategic and personal motives. Without sophisticated organisational capacity, detecting and preventing such acts is demanding for commanders. For example, utilising the practical indistinguishability between insurgents and civilians, lower-level units can easily make false claims that targeted civilians are enemies killed.

Lastly, relocation operations conducted by highly integrated forces (HIGH) are likely to be militarily successful while keeping civilian costs minimal. The rank and file is highly unlikely to avoid operation orders or use arbitrary violence when commanders are capable of evaluating both the outcome and process of operations.

In all, we suggest nuanced mechanisms that link the level of the integration of COIN forces and the outcome of displacement operations (see Table 1). When lacking force integration, a displacement operation is unlikely to damage the insurgents' support base, as soldiers refuse to follow orders to avoid risks. At the same time, members with predatory aims are likely to 
perpetrate arbitrary violence, causing considerable yet unsystematic civilian costs. When government forces are medium-integrated, soldiers are more likely to be committed to operations under the tighter control. This increased commitment of soldiers, however, can introduce new strategic incentives on top of the existing exploitative aims to perpetrate mass killing as a quick and safe way to meet operational objectives. Thus, an operation will be militarily successful yet most violent when conducted by a moderately integrated army. A relocation operation is likely to be militarily successful and least violent when it is carried out by high-integrated forces.

\section{<INSERT TABLE I HERE>}

\section{Case Selection, Method, and Research Scope}

To test our argument, we conduct in-depth case studies of three South Korean counter-guerrilla operations: operation to suppress the Jeju Uprising, Phases 1 (May-October 1948) and 2 (October 1948-February 1949); operation by the Eleventh Division (October 1950-March 1951); and the operation by Task Force Paik (December 1951-March 1952). Having been active for more than year in Jeju Island and Chiri Mountain and maintaining large spheres of influence during their respective periods, the three cases represent the most significant campaigns among numerous counter-guerrilla operations conducted in South Korea in the 1940s and 1950s. Countering them was thus critical in restoring political order in South Korea. ${ }^{28}$

\section{<INSERT FIGURE I HERE>}

\footnotetext{
${ }^{28}$ The Yeosu-Sooncheon Mutiny of 1948, another significant event during this period, is excluded since it was more of a conventional battle between the rebel and government forces.
} 
We perform structured, focused comparison based on evidence gathered from archival documents, oral history records, and truth commission reports. ${ }^{29}$ Given several shared characteristics, the cases are ideal for observing the impact of force integration on both military outcomes and civilian costs. First, despite differences in the origins of the conflicts, the guerrillas, lacking their own means, primarily relied on the local population for supplies. Second, most guerrilla activities took place in comparably mountainous terrain of Mount Halla in Jeju and the Chiri Mountain range. Third, all three cases relied heavily on civilian displacement tactics. Fourth, other variables such as regime type, state capacity and ethnicity are held constant across the cases. ${ }^{30}$ Lastly, the Korean cases are particularly puzzling as they meet the key conditions under which displacement is identified to be most effective but still demonstrate a sharp variation in outcomes. ${ }^{31}$

To operationalise force integration, we focus on the following criteria. We measure the three attributes separately and then merge them into one overall measurement of force integration. The command structure is marked high when the military had a unified and durable line of command. Conversely, command structure is measured as medium (and low) if either unification or durability of command (or both) was lacking. Monitoring is measured as high when operational commanders made systematic efforts to supervise their units. If such efforts are not evident, we measure monitoring for such cases as low. We mark quality of personnel as being high if

\footnotetext{
${ }^{29}$ Alexander George and Andrew Bennett, Case Studies and Theory Development in the Social Sciences (Cambridge: MIT Press, 2005).

${ }^{30}$ Brooks, 'Introduction'; Michael Desch, Power and Military Effectiveness the Fallacy of Democratic Triumphalism (Baltimore: Johns Hopkins University Press, 2008); Greenhill, Weapons of Mass Migration; Jason Lyall, 'Do Democracies Make Inferior Counterinsurgents? Reassessing Democracy's Impact on War Outcomes and Duration', International Organization, 64/1 (2010), 167-92; and Zhukov, 'Population Resettlement in War'.

31 The conditions for effective civilian displacement tactic are: 1) limited geographic scope of insurgency; 2) isolated insurgents; 3) small local civilian population; and 4) civilians sympathetic towards insurgents. In all three cases, the insurgents were pinched into remote mountainous areas, isolated from external support, and the size of the local population in battle zones was small. Downes, 'Draining the Sea by Filling the Graves', 438-40.
} 
government forces were recruited through a solid system and seasoned through coherent training or ample battle experience. If one or both aspects were lacking, it is marked as medium and low, respectively.

Next, we determine the overall measurement of force integration during each case. Force integration is low when two of the three attributes grade as low while the remaining one is medium or lower. Conversely, high force integration results when two attributes grade as high and the other one grades as medium or higher. All other cases that fall between the two are categorised as medium.

To evaluate the performance of civilian displacement operations, we focus on two specific outcomes: 1) damage inflicted on the insurgent supply lines; and 2) civilian casualties inflicted by government forces. For the first part, we analyse how the employment of civilian displacement tactics impacted guerrillas' supply of daily necessities, using internal documents and testimonies. An operation is considered successful if the evidence indicates negative changes occurring to guerrilla supplies following the operation.

As for civilian costs, we first discuss the overall patterns of government-perpetrated violence, including the number of civilian victims. We then examine evidence regarding the incidence of the systematic killing of civilians. An event of violence is considered systematic when soldiers attempted to target the entirety of the community.

Lastly, we briefly examine several rival explanations, such as the balance of power between insurgents and COIN forces, implementation of civil operations to win 'hearts and minds' of the population, geographical scope, and involvement of external actors. ${ }^{32}$ We discuss how these

\footnotetext{
32 Jacqueline DeMerrit, 'Delegating Death: Military Intervention and Government Killing', Journal of Conflict Resolution, 59/3 (2015), 428-54; David Galula, Counterinsurgency Warfare: Theory and Practice (Westport, CT: Praeger, 1964); and Reed Wood, 'Rebel Capability and Strategic Violence Against Civilians', Journal of Peace Research, 47/5 (2010), 601-14.
} 
factors contributed to the operational outcome at the end of our study in order to compare their explanatory power against our own. As for the research scope, our theory can travel to other types of insurgencies as long as the incumbent intends to embrace all members of the society as part of their future population but is not applicable to governments with dispossessive aims, such as genocidal or secessionist motives. ${ }^{33}$

\section{The South Korean Campaign: Case Studies}

\section{Jeju Island Uprising}

The Jeju Uprising was the first organised armed resistance against the nascent South Korean regime after its independence. On 3 April, 1948, approximately 500 poorly-armed insurgents organised by the South Korean Labor Party's (SKLP) Jeju Chapter initiated an island-wide attack on the police and right-wingers. ${ }^{34}$ As initial attempts by the Korean National Police (KNP) and local Korean Constabulary (KC) units, the forerunner of the Republic of Korea Army (ROKA), were unsuccessful, the United States Army Military Government in Korea (USAMGIK) initiated a large-scale operation in May 1948 that lasted a full year. We focus on the campaign between mid-May 1948 and February 1949, during which civilian displacement was consistently employed. Specifically, we divide the case into two phases, before and after mid-October 1948, given that the scope of displacement, which had been conducted unsystematically initially, evolved into a full-scale operation by that point.

The Eleventh (3,045 personnel led by Col. Jin-kyung Park and Lt. Col. Gyeongrok Choi, 15 May-24 July, 1948), the Ninth (2,112, Lt. Col. Yo-chan Song, 15 July-29 December, 1948), and

\footnotetext{
${ }^{33}$ Greenhill, Weapons of Mass Migration, 14-5.

${ }^{34}$ Jeju People's Guerrillas (JPG), 'Combat Report', in Changsong Moon (ed.), Hallasaneun Algoitda: Mutyeojin 4.3ui Jinsang [Halla Mountain Witnessed: The Hidden Truth of the 4.3 Incident] (Jeju: Dealim, 1995), 16-86.
} 
the Second (2,622, Lt. Col. Byung-sun Ham, after 29 December, 1948) Regiments spearheaded the Jeju operations with 1,700 KNP forces playing auxiliary roles, making the governmentinsurgent balance of power 9.4:1 (Phase 1) and 8.6:1 (Phase 2). ${ }^{35}$ Throughout the entire operation, government forces relied heavily on civilian displacement tactics. First, detention camps were constructed in coastal areas to uproot the civilians from active-insurgency zones in the mountain areas. Second, sweeping operations were conducted around the Halla Mountain region to destroy the insurgents and their strongholds. Third, screening centers were created to identify suspected leftists among the islanders. ${ }^{36}$ Civil operations were attempted by the Second Regiment in early January 1949 but were quickly discontinued after the guerrillas initiated a massive assault against the government forces and civilians. ${ }^{37}$ The US exercised control over the operation throughout, initially as the military government and later indirectly via military advisors after the establishment of Republic of Korea in August $1948 .^{38}$ The operation area was approximately $1,800 \mathrm{~km}^{2}$.

\section{1) Phase One}

Immediately after its assignment, the Eleventh Regiment started to separate civilians from the insurgents by building stone walls around villages and relocating them to detention camps in the

\footnotetext{
35 'Constitutional Assembly Record, $124^{\text {th }}$ session, December 8, 1948', in The National Investigation Committee for the Jeju 4.3 Incident (National Committee) (ed.), 4.3 Document Collection 4 (Seoul: National Committee, 2002), 105; and 'USAGIK, G-2 Periodic Report No. 1097', in National Committee (ed.), 4.3 Collection 7 (Seoul: National Committee, 2002), 123.

${ }^{36}$ John Merrill, 'The Cheju-Do Rebellion', Journal of Korean Studies, 2 (1980), 175; and Hugh Deane, The Korean War 1945-1953 (San Francisco: China Books \& Periodicals, 1999), 58.

37 'USAGIK, G-2 Periodic Report No. 1097’, 117-25.

38 'Brig. Gen. William Roberts to Lee Bum Suk, September 29, 1948', in 4.3 Collection 7, 116-7; and Robert Sawyer, Military Advisors in Korea: KMAG in Peace and War (Washington: Center of Military History, 1988), 34.
} 
coastal areas. ${ }^{39}$ The tactic would continue with the Ninth Regiment as an estimated 5,000 islanders were relocated within the first month and a half of the operation. ${ }^{40}$

During this phase, force integration of the $\mathrm{KC}$ was weak in every aspect (LOW). The command structure was divided between the constabulary and police, and suffered from abrupt changes of commanders. ${ }^{41}$ Between May and June 1948, Col. Rothwell Brown, Commander of the U.S. $20^{\text {th }}$ Regiment, briefly exercised unified command over the KC, police, and US intelligence and advising units. ${ }^{42}$ After his departure, however, no US or KC senior officer assumed the role, which suggests that the $\mathrm{KC}$ and $\mathrm{KNP}$ returned to their separate command chains. Furthermore, leadership changes persisted within the Jeju Defense Headquarters (JDHQ). To facilitate the operation, KC Headquarters established the JDHQ on 11 October, 1948, and Col. Sang-gyeom Kim again was given unified command over the constabulary, police, and naval units in Jeju. ${ }^{43}$ However, Kim was replaced by Lt. Col. Song within eight days, after the Yeo-Soon Mutiny was started by the Fourteenth Regiment under his command. ${ }^{44}$ Durability of command was further undermined with the assassination of Col. Park by a group of insurgentsympathisers within the $\mathrm{KC}$.

\section{〈INSERT FIGURE II HERE >}

\footnotetext{
${ }^{39}$ Institute for Military History (IMH), Daebijeonggyujeonsa I [History of Counter-irregular wars I] (Seoul: IMH, 1988), 59-60; Ho-Joon Huh, "The Logic of the Civilian Killings in Jeju 4.3: Focusing on the Anti-Guerrilla Operations," 4.3gwa Yeoksa [The 4.3 Incident in History], 8 (2009), 124; JPG, 'Combat Report', 32-33; and National Committee, The Jeju 4.3 Incident Investigation Report (Seoul: Sunim-sa, 2003), 218.

40 'Col. Rothwell Brown to USAMGIK, July 1, 1948', in National Committee (ed.), 4.3 Collection 9 (Seoul: National Committee, 2002), 39-42.

${ }^{41}$ Soul Park and Seung Joon Paik, 'Command Coordination and Tactical Effectiveness in Counter-insurgency Operations: Lessons from the South Korean Campaign', Small Wars and Insurgencies, 29/2 (2018), 297.

${ }^{42}$ The USAMGIK dispatched Col. Brown in May as the top commander of the operation in Jeju. 'Maj. Gen. Orland Ward to Col. Rothwell Brown, May 19, 1948', in National Committee (ed.), 4.3 Collection 8 (Seoul: National Committee, 2002), 81; and National Committee, The Jeju 4.3 Incident Investigation Report, 197.

43 'Daily Records of ROKA II, October 11, 1948', in National Committee (ed.), 4.3 Collection 5 (Seoul: National Committee, 2002), 103.

${ }^{44}$ IMH, Daebijeonggyujeonsa I, 61.
} 
Phase 1 of the operation also exposed a lack of monitoring of their units by $\mathrm{KC}$ commanders. The KC employed members of right-wing youth groups, such as the Northwest Youth Association (Seobuk Chungnyundan, NKYA), as 'elite' companies that did not belong within the regular military structure. ${ }^{45}$ Moreover, other $\mathrm{KC}$ ranking officers and the military police could not intervene in the groups' activities due to Lt. Col. Song's orders '(to) not touch the special company'. ${ }^{46}$ Employing special units is not unusual during military operations. However, without close institutional control, the use of such groups with anti-communist grievances and poor military training led to an arbitrary use of violence.

In addition, the government forces suffered from the low quality of personnel due to problems in recruitment and training. Lacking a selective recruitment system during its early years, multiple communist cells had infiltrated the $\mathrm{KC} .{ }^{47}$ As discussed later, these elements would seriously sabotage operations in various ways. As for training, soldiers of the Eleventh Regiment had only received the basic five-day training. ${ }^{48}$ The Ninth Regiment was deployed to Jeju 'for field training' by the USAMGIK on the assumption that the insurgency would be suppressed easily. ${ }^{49}$ Without a solid training program, the burgeoning Korean army had to utilise the insurgency as an opportunity for military experience.

The military outcome for Phase 1 was a failure. The guerrillas continued to collect supplies from civilians, while avoiding direct engagement with the $\mathrm{KC} .{ }^{50}$ Moreover, insurgent-

\footnotetext{
45 The NKYA consisted of youths who had fled from North Korea and were known for their radical anti-Communist activities. Soul Park, 'The Unnecessary Uprising: Jeju Island Rebellion and South Korean Counterinsurgency Experience 1947-48', Small Wars and Insurgencies, 21/2 (2010), 359-81.

${ }^{46}$ National Committee, The Jeju 4.3 Incident Investigation Report, 270.

${ }^{47}$ James Hausman, Hangook Daetongyrungul Uhmjik-in Meegun Daewhee, ed. Il-hwa Jung [The American Army Captain Who Influenced Korean Presidents] (Seoul: Hankuk Moonwon, 1995), 157; and JPG, 'Combat Report', 75.

48 Jemin Ilbo, 4.3eun Malhanda I [The 4.3 Incident Speaks I] (Seoul: Jeonyewon, 1994), 316.

49 'Maj. Gen. William Dean to KNP Director, July 30, 1948', in 4.3 Collection 9, 59-60.

${ }^{50}$ Jemin Ilbo, 4.3eun Malhanda III (Seoul: Jeonyewon, 1995), 122, 174. Also, see JPG, 'Combat Report', 78.
} 
sympathisers within the constabulary exposed the operation in various ways, including communication with the guerrillas and islanders, and even firing blank shots during operations. ${ }^{51}$ Since many civilians were able to flee before operations, a large proportion of those brought to the detention camps were young children and elders, perhaps the least valuable sources of supply for the insurgents. ${ }^{52} \mathrm{KC}$ deserters continuously provided the guerrillas with much-needed manpower, weapons, and ammunition. ${ }^{53}$ The operation was further marred by the assassination of Col. Park. Not only did the loss of the commander interrupt the pace of operation ${ }^{54}$ but suspicions of locally recruited KC soldiers also grew. Subsequently, they were placed in separate units that were seldom committed to operations, significantly reducing the strength of the constabulary.

Regarding civilian costs, Phase 1 operations saw cases of arbitrary, yet non-systematic violence. The official investigative committee of the uprising estimates that approximately 980 civilians were killed by government forces during this phase. ${ }^{55}$ While this casualty number was by no means inconsequential, it was significantly smaller in scale than the estimated 6,500 killed during Phase 2. A multi-year investigation by a newspaper, Jemin Ilbo, includes numerous instances of exploitative violence during Phase 1, yet no attempts to destroy an entire community were reported. ${ }^{56}$

1) Phase Two

\footnotetext{
${ }^{51}$ Jemin Ilbo, 4.3eun Malhanda III, 122; and JPG, 'Combat Report', 35-40.

${ }^{52}$ Deok-song Cho, 'Bloody Jeju Island', in Asia, Africa, Latin America Research Institute (ed.), Jejuminjunghangjaeng III [Jeju Popular Uprising III] (Seoul: Sonamu, 1989), 49-50.

53 JPG, 'Combat Report', 80-3.

${ }^{54} \mathrm{JPG}$, 'Combat Report', 32.

${ }^{55}$ Overall, the government was responsible for $78.1 \%$ of the civilian casualties. We applied this proportion to the 1,260 civilians killed during Phase 1 to get this estimate. National Committee, The Jeju 4.3 Incident Investigation Report, 371-2.

56 Jemin Ilbo, 4.3eun Malhanda III.
} 
It was during Phase 2 that the $\mathrm{KC}$ conducted fully-fledged civilian displacement operations.

Starting 20 October, areas $5 \mathrm{~km}$ inland from the coastline were declared forbidden territory. With the coastal areas protected by the police, the $\mathrm{KC}$ was committed to relocating the remaining civilians and fighting guerrilla forces. The constabulary burned down approximately 40,000 houses in 300 villages in the mid-mountain areas of Jeju and relocated locals to the coastal areas fortified with stone walls. ${ }^{57}$

During Phase 2, the integration of government forces improved to intermediate level (MEDIUM). Command structure became more coherent and without sudden disruptions after the consolidation of command by Lt. Col. Song in mid-October. However, evidence suggests that the command structure was still not completely clarified. At the top-level, it is unclear whether the JDHQ continued to function as a solid command center after the departure of Lt. Col. Song. No available material indicates whether Lt. Col. Ham assumed command of the headquarters from Song or whether the JDHQ was officially dissolved at all. This suggests a possibility that the headquarters functioned as an ad hoc structure and was disregarded without any official closure. In addition, a temporally divided chain of command existed within the lower ranks. ${ }^{58}$ Each battalion under the Second Regiment had two commanders assigned, one for battle and the other for administration, and their relationship is difficult to assess based on available evidence. ${ }^{59}$ Given that this arrangement was neither specified in the ROKA table of organisation nor adopted again after this specific period, it is doubtful whether such a divided command contributed to the integration of COIN forces.

\footnotetext{
57 National Committee, The Jeju 4.3 Incident Investigation Report, 377-8; and Eun-Hee Kim, 'The Formation of the Strategic Village during Jeju 4.3 and the Life of the Villagers', The Journal of Korean Historical-folklife, 23 (2006), 187.

${ }^{58}$ Sun-yup Paik, Shilrok Chiri-san [The True Record of Chiri Mountain] (Seoul: Koryeo-won, 1992), 139.

${ }^{59}$ Seock-Gyoon Chung, 'Suppression Strategy of the Military-Policy during the Jeju 4.3 Incident', Goonsa [Military History], 47 (2002), 24, 32.
} 
Force monitoring by $\mathrm{KC}$ commanders during Phase 2 remained problematic. As discussed, Lt. Col. Song allowed right-wing youth groups to operate outside the regular chain of command, and this pattern continued with the Second Regiment. ${ }^{60}$ Anecdotal evidence indicates similar problems prevailed even within regular $\mathrm{KC}$ units. For example, interviews conducted by the Institute for Military History recorded an instance in which a KC company commander went to a local tavern during the operation rather than leading his unit. ${ }^{61}$

The quality of personnel for Phase 2 demonstrated a moderate improvement. Still lacking a sophisticated training system, under-qualified individuals, such as NKYA members, were accepted to the constabulary. ${ }^{62}$ However, after purging alleged enemy infiltrators within its own ranks by November 1948, the KC did not suffer from internal sabotage of operations. The Second Regiment, moreover, was relatively more experienced since it had participated in the operation against the Yeo-Soon Mutiny before arriving in Jeju.

In terms of military outcome, Phase 2 of the operation was a success. With a relatively solidified line of command and more loyal troops, the constabulary conducted operations in a more thorough manner. Weeding out internal-sympathisers detrimentally cut insurgents' access to supplies and information from the constabulary. Testimonies of islanders indicate that the operation in late 1948 and early 1949 was the watershed moment that undermined the insurgents' supply lines. ${ }^{63}$ As many villages were destroyed, insurgents were forced to visit distant coastal areas and relied on more coercive measures to acquire food. This exacerbated situation is more

\footnotetext{
60 'Hqs., ROKA, Operations Order No. 81, May 5, 1949', 4.3 Collection 5, 26; and 'USAFIK, G-2 Periodic Report No. 1023', in 4.3 Collection 7, 103.

${ }^{61}$ Yoon Lee, 'Records of repression of the 4.3. Incident', War Diaries (2), Jeju 4.3 Archive 5, http://www.43archives.or.kr/contentDetail.do?contentMainId=MAS000000010814\&classificationId=CLA00000000 0077

${ }^{62}$ National Committee, The Jeju 4.3 Incident Investigation Report, 270.

${ }^{63}$ Jemin Ilbo, 4.3eun Malhanda III, 122, 174; and Jemin Ilbo, 4.3eun Malhanda IV (Seoul: Jeonyewon, 1997), 69.
} 
pronounced when the nature of insurgent violence is compared between Phases 1 and 2 . While the insurgents mostly killed selected targets (government officials and right-wing figures) during Phase 1, most cases of violence in Phase 2 were perpetrated while collecting food against islanders assigned to guard the coastal villages. ${ }^{64}$ In other words, the insurgents were no longer able to freely enter villages and had to risk damaging their relationship with the locals in order to obtain supplies.

Despite the successful military outcome, the operation was accompanied by instances of civilian mass killing. The Bukchon Incident, the largest event of civilian killing during the uprising, vividly demonstrates the systematic nature of violence perpetrated by government forces. On 17 January, 1949, the guerrillas ambushed a company from the Second Regiment, killing two soldiers. Immediately afterwards, the company entered nearby Bukchon, burned down 300 houses and indiscriminately murdered hundreds of villagers, including children and seniors, accusing them as enemy supporters. ${ }^{65}$ The killing only stopped when the battalion's commander reached the scene and aimed a pistol at the company commander to get him to stop the killing. ${ }^{66}$ This signals a lack of solid command as even a junior officer's arbitrary decision could spur a civilian mass killing. The incident is one of numerous cases of systematic killing perpetrated during this phase. It is estimated that 6,527 civilians were killed by the government forces. $^{67}$

Overall, our Jeju case study supports our theory. With moderate improvements in force integration between Phases 1 and 2, KC soldiers during the later operations were more

\footnotetext{
${ }^{64}$ National Committee, The Jeju 4.3 Incident Investigation Report, 438.

${ }^{65}$ Boo-il Jeon, Naeireul Wihae Oneure Salda [Living Today for Tomorrow] (Seoul: Daedomunhwasa, 1993), 257-8; and Sun-sik Hong, 'Mass Murder in Bukchon', in Sung-chan Oh (ed.), Hallaui Tonggong Sori [Wailing Sound in Halla] (Seoul: Sonamu, 1988), 57-9.

${ }^{66}$ Hong, 'Mass Murder in Bukchon', 58.

${ }^{67}$ National Committee, The Jeju 4.3 Incident Investigation Report, 368-9, 371-2.
} 
committed to the military objectives and successfully undermined the insurgent support base.

Still lacking a sophisticated organisational capacity to regulate arbitrary use of violence, however, the constabulary's more integrated, aggressive use of force transformed into significantly higher, systematic civilian casualties.

\section{Eleventh Division Operations}

A few months after the outbreak of the Korean War, the ROKA and the United Nations Command (UNC) forces faced fighting on two fronts: a conventional war against North Korea (and later Chinese forces), and partisan threat in the rear. Once the war commenced, the North Korean People's Army (KPA) rapidly pierced through the outnumbered and outgunned ROKA defence lines and occupied most of the Korean peninsula. ${ }^{68}$ However, the situation was quickly reversed once 75,000 UNC forces had successfully landed in Inchon and regained control of the central region of the peninsula. By 28 September, 1950, a significant number of KPA soldiers initially deployed to the South were isolated inside the ROK territory. ${ }^{69}$

North Korea utilised these isolated forces to disrupt internal stability of the ROK as Kim IlSung ordered them to 'cut enemy supply line, assault enemy leadership, and expand liberated zones ${ }^{70}$ An estimated 10,000 stranded KPA soldiers and SKLP members based in Chiri Mountain area carried out guerrilla attacks. ${ }^{71}$ Even after the UNC forces advanced past the $38^{\text {th }}$ parallel, South Korea did not have complete control over the southwestern region of the peninsula. Out of the 338 local police posts in Jeolla Province, 258 were still controlled by the

\footnotetext{
${ }^{68}$ Allan Millett, The War for Korea, 1950-1951: They Came from the North (Lawrence: University Press of Kansas, 2010), 186-8.

${ }^{69}$ Roy Appleman, South to the Naktong, North to the Yalu (Washington: Center of Military History, 1961), 721.

${ }^{70}$ Yong-jo Yang, 'Operationalization and Characteristics of North Korean Guerrilla during the Korean War', The Journal of Historical Studies, 10 (2003), 455.

${ }^{71}$ IMH, Daebijeonggyujeonsa I, 167.
} 
guerrillas in late October 1950, and those under the ROK control could barely defend their surrounding areas. ${ }^{72}$

To suppress the remaining communist-occupied zones in the south, the ROKA created the Eleventh Division. From 4 October, 1950 to 30 March, 1951, the Ninth, Thirteenth and Twentieth Regiments of this division conducted operations in South Gyeongsang, North and South Jeolla Provinces, respectively. Roughly 10,000 army and police personnel were committed, approximately equaling guerrilla strength. As in Jeju, the Eleventh Division primarily relied on civilian displacement tactics. ${ }^{73}$ Soldiers relocated the population and crops to government-controlled areas and burned down houses to deny guerrilla sanctuary. ${ }^{74}$ According to available materials, the division did not engage in civil operations nor were American military advisors involved. The division conducted operation in 33 counties and cities, approximately $18,000 \mathrm{~km}^{2}$.

The overall force integration of the Eleventh Division was moderate (MEDIUM). First, command structure showed notable improvements, as Gen. Duk-sin Choi was in charge for the full duration of the campaign. Likewise, the lower-level units maintained a unified command structure unlike the units in Phase 2 of Jeju operations.

In terms of monitoring, division officers failed to closely supervise their units due to a lack of commitment and the size of the operation zones. In his memoir, Gen. Choi described his division as 'second class', expressing his disinterest in counter-guerrilla operations. ${ }^{75}$ Mid-ranking

\footnotetext{
${ }^{72}$ Bruce Cumings, The Origins of the Korean War, Vol. II (Berkeley: University of California Press, 1967), 689; and Paik, Shilrok Chiri-san, 321.

${ }^{73}$ Hqs. Eleventh Division, 'Early History of the Eleventh Division', June 22, 1951 in ROKA Headquarters (ed.), The Korean War Material Collection 59 (Seoul: ROKA Headquarters, 1988), 172.

${ }^{74}$ Gwanho Jeong, Jeonnam Yugyeogtujaengsa [History of Guerrilla Resistance in South Jeolla Province] (Seoul: Seonin, 2008), 102; and Paik, Shilrok Chiri-san, 320.

${ }^{75}$ Duk-sin Choi, Namhanttange 30 Nyeon [Thirty Years in South Korea] (Tokyo: Unification Press, 1985), 65.
} 
officers showed similar sentiments. The commander of the Ninth Regiment, Col. Ik-kyeong Oh, did not show up at massacre sites even after the atrocities that his troops committed became a nation-wide scandal. ${ }^{76}$ In an internal document circulated in January 1951, the operations chief of the division reported that many officers often stayed far behind the action zone to avoid direct engagement. Moreover, many made deliberate efforts to evade supervision by cutting communications with headquarters. ${ }^{77}$ Given the relatively large area covered, the Eleventh division had to conduct operations in a dispersed fashion, further undermining the commander's ability to supervise.

The level of personnel quality was intermediate. After undergoing an extensive anticommunist campaign in 1949, the ROKA did not experience serious loyalty issues due to poor recruitment processes. ${ }^{78}$ The division, however, had problems in training and combat experience. The army's nascent training system collapsed with the outbreak of the Korean War, and many newly conscripted soldiers were ill-prepared prior to deployment. ${ }^{79}$ Indeed, Gen Choi admitted that the hastily deployed division suffered from a lack of discipline.$^{80}$ For example, the use and maintenance of crew-served weapons, such as mortars and machine guns, were limited, sometimes simply because they were deemed too heavy to carry. ${ }^{81}$

Evidence suggests that the operation successfully weakened the guerrillas. According to the People's Guerrillas in South Gyeongsang Province's internal report, the group lost all the three

\footnotetext{
76 Joongang Ilbo, Minjogui Jeungeon 4 [Testimony of Nation 4] (Seoul: Joongang Ilbo, 1983), 200.

${ }^{77}$ Hqs. Eleventh Division, January 23, 1951, 'Guidance for Commanding Officers', in In-sup Han (ed.), The Geochang Incident Document Collection III (Seoul: SNU, 2003), 1-4.

${ }^{78}$ Hausman, Hangook Daetongyrungul Uhmjik-in Meegun Daewhee, 190-5.

${ }^{79}$ Bryan Gibby, The Will to Win: American Military Advisers in Korea, 1946-1953 (Tuscaloosa: University of Alabama Press, 2012), ch.7.

${ }^{80}$ Truth and Reconciliation Commission (TRC), Second 2009 Report, vol. 7 (Seoul: TRC, 2009), 659-60.

${ }^{81}$ Hqs. Eleventh Division, 'Guidance for Commanding Officers'.
} 
townships under its control by the end of March $1951 .{ }^{82}$ Groups in the Jeolla region also lost most of the liberated areas during this period. The Communists readily admitted that their activity was 'extremely weak except for the defensive struggle' during the Eleventh Division's operations. ${ }^{83}$ Further capitulation or desertion followed due to severe weather and food shortage. Consequently, guerrillas had to sneak into the police-protected villages and coerce civilians for supplies, a plan that was risky and exacerbated their relationship with the general population.

Regarding civilian costs, numerous instances of systematic killing, on top of widespread materially and sexually-driven violence, were perpetrated during the operation. ${ }^{84}$ A police chief who assisted the operation bitterly called the Eleventh Division 'the public harm division', as some units 'acted as if their primary task was to pose threats to civilians and the local government' ${ }^{85}$ In addition, there were many instances in which civilians who failed to leave their houses on time or keep pace with the soldiers were simply shot. ${ }^{86}$ Moreover, the troops attempted to murder entire villages in multiple localities during the operation. Overall, approximately 2,500 civilians were identified as victims of the Eleventh Division by the TRC and the government council on the incidents in Geochang and neighboring counties. ${ }^{87}$

\footnotetext{
${ }^{82}$ South Gyeongsang People's Guerrillas (SGPG), 'About the Guerrilla Struggle', 10 July, 1951, in Hallym Institute of Asia Culture Studies (HIACS) (ed.), Partisan Collection II (Chuncheon: HIACS, 1996), 2-60; and Jong-Jun Kim, 'The Partisan's Organization and Activities in the Western Kyungnam Province during the Korean War: In the Center of the Period from October 1950 to June 1951', Korean Journal of Genocide Studies, 2 (2007), 37.

${ }^{83}$ SGPS, 'About the Guerrilla Struggle', 52-4.

${ }^{84}$ Choi, Namhanttange 30 Nyeon, 69; Joongang Ilbo, Minjogui Jeungeon 4, 202; TRC, First 2010 Report, vol. 5 (Seoul: TRC. 2010), 748-9; and Min-yong Roh and Hee-jung Kang, Geochangyangminhagsal: Geu Ijhyeojin Piuleum [Geochang Incident: The Forgotten Bloody Tears] (Chung-ju: Onuri, 1988), 88.

${ }^{85}$ Du-un Kim, Jirisan Gonghwaguk [Chiri Mountain Republic] (Seoul: Shinsaedaesa, 1991), 342-3.

${ }^{86}$ TRC, First 2010 Report, vol. 5, 777.

87 TRC, First 2007 Report (Seoul: TRC, 2007); TRC, Second 2008 Report, vols. 2-3 (Seoul: TRC, 2008); TRC, First 2009 Report, vol. 4 (Seoul: TRC, 2009); TRC, First 2010 Report, vols. 3-4, 8 (Seoul: TRC, 2010); and TRC, Second 2009 Report, vol. 7.
} 
One example of this systematic killing is the Geochang Massacre. On 5 February, 1951, the Third Battalion, Ninth Regiment, reclaimed Shinwon-myeon in Geochang County under a regiment operation order to shoot 'civilians in the hands of the enemy'. ${ }^{88}$ After deploying defence personnel, the battalion left without further action. ${ }^{89}$ As the guerrillas returned to attack the township a few days later, however, the battalion commander was scolded by the regiment commander and tasked with 'addressing the situation' ${ }^{90}$ This ended with the battalion perpetrating systematic mass killing in multiple villages in Geochang, Sancheong, and Hamyang Counties. ${ }^{91}$ In Shinwon-myeon alone, 719 civilians were killed, including hundreds of children and seniors. ${ }^{92}$ To cover up this arbitrary killing, the regiment falsely equated casualty numbers to guerrillas killed in its after-action report to division headquarters. ${ }^{93}$ This mass killing soon provoked a nation-wide scandal, resulted in the replacements of Ministers of National Defense, Internal Affairs, and Justice, and abruptly ended the operation itself in early April 1951.

Again, the second case study is consistent with our thesis. As with Phase 2 Jeju operations, soldiers of the moderately-integrated Eleventh Division successfully damaged the support base of the guerrillas in Chiri Mountain. However, due to the various internal problems within the division, such as poor supervision and inexperienced personnel, the division headquarters was unable to control the systematic killing of 2,500 civilians perpetrated by its units.

\footnotetext{
${ }^{88}$ The regiment commander admitted that he arbitrarily issued this operation order without consulting the division headquarters. Sung-hoon Han, Gamyeongwollyeong Hangukjeonjaenggwa Haksal [Disguised Power: the Korean War and Massacres] (Seoul: Humanitas, 2014), 146; and Military Police Headquarters, 28 May, 1951, 'Interrogation of Dong-suk Han' and Military Police Headquarters, 10 June, 1951, 'Interrogation of Ik-kyung Oh', in Geochang Collection III, 28-34 and 35-9.

89 'Interrogation of Dong-suk Han'; TRC, First 2010 Report, vol. 5, 777.

${ }^{90}$ KNP Headquarters, Daily Enemy Activity, 11 February, 1951, in HIACS (ed.) Partisan Collection III (Chuncheon: HIACS, 1996), 153-8.

${ }^{91}$ Han, Gamyeongwollyeong Hangukjeonjaenggwa Haksal, 146-9; and National Assembly Committee on Civilian Massacre, Investigative Report on Civilian Massacre, 4th National Assembly, 35th session, 1960.

${ }^{92}$ National Assembly Committee, Investigative Report on Civilian Massacre.

${ }^{93}$ Choi, Namhanttange 30 Nyeon, 70.
} 


\section{Task Force Paik}

Once the Chinese People's Volunteer Army (CPVA) intervened and pushed back the UNC forces with a series of offensives, the Korean War evolved into a stalemate by mid-1951. While the conventional fighting gradually subsided around the $38^{\text {th }}$ parallel, approximately 4,000 remaining guerrillas in the south were reinvigorated under the command of Hyun-sang Lee, an experienced guerrilla leader dispatched from the North during the CPVA's Spring Offensives. New weapons were distributed and most of the existing guerrillas were reorganised under his command. ${ }^{94}$ The guerrillas launched large-scale attacks on nearby areas with new-found vigor, continuously disrupting the ROKA's supply routes. ${ }^{95}$

It is within this context that the Korean National Assembly voted for military operations to restore internal order. On 16 November, 1951, Task Force Paik was created to conduct Operation Ratkiller. With 30,000 military and police personnel, the taskforce enjoyed favorable balance of power (7.5:1). ${ }^{96}$ The US Military provided reconnaissance planes and radio broadcasting equipment. ${ }^{97}$ The two divisions committed for the mission were the ROKA's Capital Division (Gen. Yo-chan Song) and the Eighth Division (Gen. Young-hi Choi). The primary objective of the operation was to 'eliminate domestic Communist guerrillas and destroy all of their supplies' ${ }^{98}$ The taskforce also conducted psychological and civic operations. ${ }^{99}$

\footnotetext{
94 Tae Lee, Nambugun [Southern Corps] (Seoul: Yeolim, 1988), 211.

${ }^{95}$ IMH, Daebijeonggyujeonsa I, 183-5.

96 TRC, First 2010 Report, vol. 5, 750.

${ }^{97}$ Paik, Shilrok Chiri-san, 27.

${ }^{98}$ ROKA Headquarters, Gongbitobeolsa [History of Counterguerrilla Operations] (Seoul: ROKA Headquarters, 1954), 81.

${ }^{99}$ According to former guerrillas, however, such operations were largely considered as false propaganda. Tae Lee, Nambugun 2 [Southern Corps 2] (Seoul: Doore, 1988), 142.
} 
From the onset, the two divisions in coordination with police forces completely encircled the Chiri Mountain and conducted 'rabbit-hunting' style mop-up operations all the way up to the top. Civilians were relocated to nearby 'collective villages (jeonryak-chon)', which were doubly fortified with stone and bamboo walls and guarded by ROKA or police forces. ${ }^{100}$ All crops and livestock were put into collective storage at night, and each household was rationed a daily portion the next morning. Taskforce units seized or destroyed concealed crops found in operation zones via information collected from captives. ${ }^{101}$ Civilians in deep mountain areas, mostly either communist sympathisers or those who fled from potential abuses by government forces, were captured and sent to detention camps in Namwon and Gwangju. ${ }^{102}$ The taskforce operated in 16 ROK-controlled counties and cities, about $9,750 \mathrm{~km}^{2}$ areas of land.

Force integration of the taskforce was high in every aspect (HIGH). Regarding the command structure, both army divisions and the auxiliary police battalions were under the official command of Gen. Sun-yup Paik ${ }^{103}$ without any leadership changes throughout. ${ }^{104}$ Specifically, Gen. Paik was deeply involved in the formation of the taskforce and detailed its operational plans with the support of Gen. James Van Fleet, commander of the US Eighth Army and UN forces.

Second, Paik and the other senior commanders exerted considerable effort to monitor their units in action by using reconnaissance planes. Troops were ordered to carry red identification panels, which made monitoring easier aboard planes in the snow-covered mountains. Due to such efforts, the long-standing problem of false after-action reports concocted by junior officers

\footnotetext{
${ }^{100}$ Paik, Shilrok Chiri-san, 28, 54.

101 Jeong, Jeonnam Yugyeogtujaengsa, 103.

102 TRC, First 2010 Report, vol. 5, 787.

${ }^{103}$ Gen. Paik passed away in 2020. For more, see Sang-Hun, Choe, 'Paik Sun-yup, Lightning Rod General in South Korea, Dies at 99', New York Times, 11 July 2020, <https://www.nytimes.com/2020/07/11/world/asia/Paik-Sunyup-Korea-dies.html>

${ }^{104}$ Hyekyung Kang, 'Security Maintaining in the Rear and Police for Korean War', Studies in Humanities, 30 (2011), 277-8.
} 
was largely corrected. ${ }^{105}$ Third, by this stage soldiers were far more experienced in comparison to the previous campaigns. The Capital and Eighth Divisions had gained considerable combat experience at the frontlines and in the Chiri Mountain areas, respectively.

Many former guerrillas recall Task Force Paik's operations as the most effective campaign launched against them. ${ }^{106}$ Due to the draining-the-sea tactics employed, insurgents who survived the operations suffered from severe supply shortage and oftentimes risked their lives to collect food from nearby towns. ${ }^{107}$ As many former insurgents recollect, such difficulties led to desperation and forced them to rely more on coercive measures, which eventuated in a worsened relationship with the population base. ${ }^{108}$ Lacking consistent supply bases, most guerrillas had to walk and sleep on snowy mountains without proper shelter or clothing for extended periods of time. ${ }^{109}$ Thus, securing food and other daily supplies became the top priority for the insurgents' military wings rather than disturbing the ROK governance structure. ${ }^{110}$

At the same time, the counter-guerrilla forces were able to relocate civilians less violently. Gen. Paik directed that 'no individual or unit should fire at anyone who was not in the act of resisting'. ${ }^{111}$ A police commander who participated in the operations described the campaign as 'systematic, modernized, and well-disciplined'. ${ }^{112}$ The number of reported cases of civilian killing dropped considerably; the Pan-National Committee report, which records 669 alleged

\footnotetext{
105 Paik, Shilrok Chiri-san, 34-6.

106 Kim, Jirisan Gonghwaguk, 39.

107 Jeong, Jeonnam Yugyeogtujaengsa, 103.

108 Jia Jeong, Ppalchisanui Ttal 2 [A Partisan's Daughter 2] (Seoul: Silcheonmunhaksa, 1990), 215; Lee, Nambugun 2, 69; and Yong-taek Kim, 'The Rebuilding and Collapse of the Communist Partisan in South Korea', Journal of Korean Modern and Contemporary History, 27 (2003), 124-227.

${ }^{109}$ Lee, Nambugun 2, 112; and Jeong, Jeonnam Yugyeogtujaengsa, 106.

110 Jeong, Jeonnam Yugyeogtujaengsa, 172.

${ }^{111}$ Mark Reardon, 'Chasing a Chameleon: The US Army Counterinsurgency Experience in Korea, 1945-1952', in Richard Davis (ed.), The US Army and Irregular Warfare, 1775-2007 (Washington, DC: Center of Military History, 2008), 226.

112 Kim, 'The Partisan's Organization and Activities in the Western Kyungnam Province', 342-3.
} 
events of civilian killing, does not include a single case perpetrated by the taskforce. ${ }^{113}$ Similarly, a report by the Truth and Reconciliation Commission include six victimised civilians during forced displacement but no systematic killings perpetrated by the taskforce. ${ }^{114}$

This does not necessarily mean that the taskforce's operations were conducted without violence, as many civilians in detention camps died in harsh conditions. ${ }^{115}$ In addition, it is still possible that the ROKA's war record includes civilian victims who were falsely reported as guerrillas killed. ${ }^{116}$ Yet, based on the available evidence, it is clear that the frequency and scale of the killings perpetrated by the ROKA dropped significantly compared to the previous operations.

As suggested by our theory, the operation conducted by the highly integrated Task Force Paik was both militarily successful and less violent. Utilising strong organisational capacity, commanders of the taskforce were able to trace the process of the operation in greater detail and ultimately reduce the use of arbitrary violence by its soldiers.

\section{<INSERT TABLE II HERE>}

\section{Conclusion}

Our case studies of the South Korean campaign demonstrate that implementation of civilian displacement tactics can vary dramatically depending on the integration of security forces conducting the operations (see Table II). Specifically, a unified and durable command structure, the commanding officers' efforts to actively monitor operational developments, and high-level of

\footnotetext{
${ }^{113}$ Pan-National Committee for Civilian Massacres, Hangukjeonjaengjeonhu Minganinhaksal Siltaebogoseo [Report on Civilian Massacre Before and After the Korean War] (Paju: Hanul, 2005), 11.

114 TRC, First 2010 Report, vol. 5, 76-8.

115 Jeong, Jeonnam Yugyeogtujaengsa, 159.

${ }^{116}$ Du-un Kim, Jirisan Horangi [A Tiger in Chiri Mountain] (Seoul: Woosuk, 1989), 167.
} 
qualification of personnel gained via solid recruitment, training, and combat experience were factors that led to the successful cutting-off of the insurgents from the population base with reduced civilian costs. When these factors are partially developed, however, relocation operations potentially result in systematic violence against civilians, as demonstrated by the Jeju Phase 2 and Eleventh Division operations. These two operations were significantly more successful in undermining the guerrilla support when compared to the Phase 1 Jeju operation, yet with an overwhelmingly greater numbers of civilian deaths.

Other rival explanations do not demonstrate strong explanatory power. Regarding the balance of power between the COIN forces and guerrillas, and the geographical scope of operations, the government forces committed to the Jeju Uprising were in the most favorable conditions, facing poorly armed pockets of guerrilla resistance in the smallest land areas. However, the later operation by the Eleventh Division was more, or at least equally, successful on military grounds despite being in a relatively disadvantageous position. Civil operations similarly do not offer strong plausibility. Although the amnesty program were used during phase two of the Jeju operation and later by Task Force Paik, the former was merely utilised by the insurgents as an opportunity for aggression while the latter was largely dismissed as propaganda. Lastly, the involvement of American military advisors cannot explain the outcomes of our cases. While US advisors were deeply involved in both Jeju operations and the Operation Ratkiller, the consequences varied dramatically.

While additional analysis is required to further establish the causal mechanism between force integration, military outcomes, and civilian killings during displacement operations, our research holds several implications. First, our research contributes to the emerging scholarship on civilian displacement. Despite recent consideration of displacement tactics as a distinct type of political 
violence, few have focused on the degree of violence. Given that civilian displacement continues to be a popular COIN tool in the post-Cold War era, analyzing the dynamics of violence can help us better prepare for humanitarian efforts in ongoing and future conflicts.

In addition, this study suggests a counterintuitive, non-linear relationship between force integration and the level of violence against civilians during relocation operations. While an improvement to intermediate level of force integration can lead to a more militarily successful outcome, it can also provoke a greater scale of violence against civilians. This can be a serious challenge for a burgeoning army that is unable to invest considerable resources to further improve its organisational capacity. Following our research, we recommend the commanders of newly developing armies to distribute their limited organisational capabilities wisely and plan operations moderately. As our Eleventh Division case study demonstrates, even a militarily successful operation can be disrupted if it generates civilian costs that ultimately damage the legitimacy of the government.

Moreover, our findings highlight the importance of effective oversight during civilian displacement operations, as COIN is a context in which soldiers perceive considerable threats from civilians and war crimes can be easily covered up. Contrary to recent studies that have emphasized the autonomy of lower-level units, ${ }^{117}$ we suggest that autonomy without a solid command could be risky from both military and humanitarian perspectives. This is more pronounced for security forces that are not at the level of advanced military organisations, especially indigenous forces of newly-established countries. Relatedly, we urge caution in

\footnotetext{
117 John Nagl, Learning to Eat Soup with a Knife: Counterinsurgency Lessons from Malaya and Vietnam (Chicago: University of Chicago Press, 2005); Talmadge, The Dictator's Army; and Felter, 'Sources of Military Effectiveness in Counterinsurgency', 134-5.
} 
outsourcing civilian-related operations to private companies as similar principal-agent problems may arise.

Lastly, our in-depth study of an underexplored case contributes empirically and policy-wise to the study of the Korean peninsula. Empirically, despite being one of the more successful COIN cases of the early Cold War period, the South Korean case, especially ROKA Eleventh Division operations, has rarely received rigorous academic attention compared to those in Greece, the Philippines, and Malaysia. ${ }^{118}$ As such, our analysis is one of the first attempts to systematically address counter-guerrilla operations from a micro-level perspective as well as examine neglected civilian massacres perpetrated before and during the Korean War period. In terms of policy, our study provides broad lessons to military planners and civilian policy-makers in preparing for potential low-intensity conflict arising on the Korean peninsula.

\section{Bibliography}

Appleman, Roy, South to the Naktong, North to the Yalu (Washington: Center of Military History, 1961).

Arreguín-Toft, Ivan, 'How the Weak Win Wars: A Theory of Asymmetric Conflict', International Security, 26/1 (2001), 93-128.

Axelrod, Robert, and William Hamilton, 'The Evolution of Cooperation', Science, 211/4489 (1981), 1390-96.

Bakke, Kristin, Kathleen Gallagher Cunningham, and Lee J. M. Seymour, 'A Plague of Initials: Fragmentation, Cohesion, and Infighting in Civil Wars', Perspectives on Politics, 10/2 (2012), 265-83.

Balcells, Laia, 'Rivalry and Revenge: Violence against Civilians in Conventional Civil Wars', International Studies Quarterly, 54/2 (2010), 291-313.

Blair, Graeme, Kosuke Imai, and Jason Lyall, 'Comparing and Combining List and Endorsement Experiments: Evidence from Afghanistan', American Journal of Political Science, 58/4 (2014), 1043-63.

Brooks, Risa, 'Introduction: The Impact of Culture, Society, Institutions, and International Forces on Military Effectiveness', in Risa Brooks and Elizabeth Stanley (eds.), Creating Military Power: The Sources of Military Effectiveness (Stanford: Stanford University Press, 2007), 1-26.

\footnotetext{
${ }^{118}$ Robert Ramsey, Advising Indigenous Forces: American Advisors in Korea, Vietnam, and El Salvador (Fort Leavenworth: Combat Studies Institute Press, 2006), 1.
} 
Cho, Deok-song, 'Bloody Jeju Island', in Asia, Africa, Latin America Research Institute (ed.), Jejuminjunghangjaeng III [Jeju Popular Uprising III] (Seoul: Sonamu, 1989), 44-52.

Choe, Sang-Hun, 'Paik Sun-yup, Lightning Rod General in South Korea, Dies at 99', New York Times 11 Jul. 2020, <https://www.nytimes.com/2020/07/11/world/asia/Paik-Sun-yup-Korea-dies.html>

Choi, Duk-sin, Namhanttange 30 Nyeon [Thirty Years in South Korea] (Tokyo: Unification Press, 1985).

Chung, Seock-Gyoon, 'Suppression Strategy of the Military-Policy during the Jeju 4.3 Incident', Goonsa [Military History], 47 (2002), 9-36.

Cohen, Dara Kay, 'Explaining Rape during Civil War: Cross-National Evidence (1980-2009)', American Political Science Review, 107/3 (2013), 461-77.

Condra Luke, and Jacob Shapiro, 'Who Takes the Blame? The Strategic Effects of Collateral Damage', American Journal of Political Science, 56/1 (2012), 167-87.

Cumings, Bruce, The Origins of the Korean War, Vol. II (Berkeley: University of California Press, 1967)

Deane, Hugh, The Korean War 1945-1953 (San Francisco: China Books \& Periodicals, 1999).

DeMerrit, Jacqueline, 'Delegating Death: Military Intervention and Government Killing', Journal of Conflict Resolution, 59/3 (2015), 428-54.

Desch, Michael, Power and Military Effectiveness the Fallacy of Democratic Triumphalism (Baltimore: Johns Hopkins University Press, 2008).

Downes, Alexander, 'Draining the Sea by Filling the Graves: Investigating the Effectiveness of Indiscriminate Violence as a Counterinsurgency Strategy', Civil Wars 9/4 (2007), 420-44.

Downes, Alexander, Targeting Civilians in War (Ithaca: Cornell University Press, 2008).

Felter, Joseph, 'Sources of Military Effectiveness in Counterinsurgency: Evidence from the Philippines', in Dan Reiter (ed.), The Sword's Other Edge: Trade-offs in the Pursuit of Military Effectiveness (Cambridge: Cambridge University Press, 2017), 126-60.

Fjelde, Hanne, and Indra De Soysa, 'Coercion, Co-Optation, or Cooperation?: State Capacity and the Risk of Civil War, 1961-2004', Conflict Management and Peace Science, 26/1 (2009), 5-25.

Galula, David, Counterinsurgency Warfare: Theory and Practice (Westport, CT: Praeger, 1964).

George, Alexander, and Andrew Bennett Case Studies and Theory Development in the Social Sciences (Cambridge: MIT Press, 2005).

Gibby, Bryan, The Will to Win: American Military Advisers in Korea, 1946-1953 (Tuscaloosa: University of Alabama Press, 2012).

Gill, Paul, and John Horgan, 'Who Were the Volunteers? The Shifting Sociological and Operational Profile of 1240 Provisional Irish Republican Army Members', Terrorism and Political Violence, 25/3 (2013), 435-56.

Greenhill, Kelly, 'Draining the Sea, or Feeding the Fire?: The Use of Civilian displacement in Counterinsurgency Operations', Paper presented at the American Political Science Association Annual Meeting, Chicago, IL, 2 September 2004.

Greenhill, Kelly, 'Strategic Engineered Migration as a Weapon of War', Civil Wars, 10/1 (2008), 621.

Greenhill, Kelly, Weapons of Mass Migration: Forced Displacement, Coercion, and Foreign Policy (Ithaca: Cornell University Press, 2010).

Grossman, Dave, On Killing: The Psychological Cost of Learning to Kill in War and Society (New York: Back Bay Books, 1995).

Han, In-sup (ed.), Geochang Yangmin Hagsal Sageon Jalyojib III: Jaepan Jalyo Pyeon [Geochang Massacres Document Collection III: Legal Documents] (Seoul: The SNU Law Research Institute, 2003).

Han, Sung-hoon, Gamyeongwollyeong Hangukjeonjaenggwa Haksal [Disguised Power: the Korean War and Massacres] (Seoul: Humanitas, 2014).

Hack, Karl, 'The Malayan Emergency as Counter-Insurgency Paradigm', Journal of Strategic Studies, 32/3 (2009), 383-414. 
Hallym Institute of Asia Culture Studies, (ed.), Partisan Collection II: Internal Documents (Chuncheon: Hallym Institute of Asia Culture Studies, 1996).

Hallym Institute of Asia Culture Studies, (ed.), Partisan Collection III: Police Documents (Chuncheon: Hallym Institute of Asia Culture Studies, 1996).

Hausman, James, Hangook Daetongyrungul Uhmjik-in Meegun Daewhee, ed. Il-hwa Jung [The American Army Captain Who Influenced Korean Presidents] (Seoul: Hankuk Moonwon, 1995).

Hazelton, Jacqueline, 'The "Hearts and Minds" Fallacy: Violence, Coercion, and Success in Counterinsurgency Warfare', International Security, 42/1 (2017), 80-113.

Hegghammer, Thomas, 'The Recruiter's Dilemma: Signaling and Rebel Recruitment Tactics', Journal of Peace Research, 50/1 (2013), 3-16.

Hoover Green, Amelia, 'The Commander's Dilemma: Creating and Controlling Armed Group Violence', Journal of Peace Research, 53/5 (2016), 619-32.

Hong, Sun-sik, 'Mass Murder in Bukchon Village', in Sung-chan Oh (ed.), Hallaui Tonggong Sori [Wailing Sound in Halla] (Seoul: Sonamu, 1988), 57-9.

Huh, Ho-Joon, 'The Logic of the Civilian Killings in Jeju 4.3: Focusing on the Anti-Guerrilla Operations', 4.3gwa Yeoksa [The 4.3 Incident in History], 8 (2009), 102-61.

Humphreys, Macartan, and Jeremy Weinstein, 'Handling and Manhandling Civilians in Civil War', American Political Science Review, 100/3 (2006), 429-47.

Institute for Military History, Daebijeonggyujeonsa I [History of Counter-irregular wars I] (Seoul: Institute for Military History, 1988).

Jemin Ilbo, 4.3eun Malhanda I [The 4.3 Incident Speaks I] (Seoul: Jeonyewon, 1994).

Jemin Ilbo, 4.3eun Malhanda III [The 4.3 Incident Speaks III] (Seoul: Jeonyewon, 1995).

Jemin Ilbo, 4.3eun Malhanda IV [The 4.3 Incident Speaks IV] (Seoul: Jeonyewon, 1997).

Jemin Ilbo, 4.3eun Malhanda V [The 4.3 Incident Speaks V] (Seoul: Jeonyewon, 1998).

Jeon, Boo-il, Naeireul Wihae Oneure Salda [Living Today for Tomorrow] (Seoul: Daedomunhwasa, 1993).

Jeong, Jia, Ppalchisanui Ttal 2 [A Partisan's Daughter 2] (Seoul: Silcheonmunhaksa 1990).

Jeong, Gwanho, Jeonnam Yugyeogtujaengsa [History of Guerrilla Resistance in South Jeolla Province] (Seoul: Seonin, 2008).

Joongang Ilbo, Minjogui Jeungeon 4 [Testimony of Nation 4] (Seoul: Joongang Ilbo Corporation, 1983).

Kalyvas, Stathis, The Logic of Violence in Civil War (New York: Cambridge University Press, 2006).

Kang, Hyekyung, 'Security Maintaining in the Rear and Police for Korean War', Studies in Humanities, 30 (2011), 173-204.

Kim, Du-un, Jirisan Horangi [A Tiger in Chiri Mountain] (Seoul: Woosuk, 1989).

Kim, Du-un, Jirisan Gonghwaguk [Chiri Mountain Republic] (Seoul: Shinsaedaesa, 1991).

Kim, Eun-Hee, 'The Formation of the Strategic Village during Jeju 4.3 and the Life of the Villagers', The Journal of Korean Historical-folklife, 23 (2006), 181-210.

Kim, Jong-Jun, 'The Partisan's Organization and Activities in the Western Kyungnam Province during the Korean War: In the Center of the Period from October 1950 to June 1951', Korean Journal of Genocide Studies, 2 (2007), 15-61.

Kim, Yong-taek, 'The Rebuilding and Collapse of the Communist Partisan in South Korea', Journal of Korean Modern and Contemporary History, 27 (2003), 124-227.

King, Anthony, The Combat Soldier: Infantry Tactics and Cohesion in the Twentieth and TwentiethFirst Centuries (Oxford: Oxford University Press, 2013).

Lee, Tae, Nambugun [Southern Corps] (Seoul: Yeolim, 1988).

Lee, Tae, Nambugun 2 [Southern Corps 2] (Seoul: Doore, 1988).

Lee, Yoon, 'Records of repression of the 4.3. Incident', War Diaries (2). Jeju 4.3 Archive, http://www.43archives.or.kr/contentDetail.do?contentMainId=MAS000000010814\&classificatio nId $=$ CLA000000000077 
Lyall, Jason, and Isaiah Wilson, 'Rage Against the Machines: Explaining Outcomes in Counterinsurgency Wars', International Organization, 63/1 (2009), 67-106.

Lyall, Jason, 'Do Democracies Make Inferior Counterinsurgents? Reassessing Democracy's Impact on War Outcomes and Duration', International Organization, 64/1 (2010), 167-92.

Lyall, Jason, Graeme Blair, and Kosuke Imai, 'Explaining Support for Combatants during Wartime: A Survey Experiment in Afghanistan', American Political Science Review, 107/4 (2013), 679-705.

Manekin, Devorah, 'The Limits of Socialization and the Underproduction of Military Violence: Evidence from the IDF', Journal of Peace Research, 54/5 (2017), 606-19.

Mao, Zedong, On Guerrilla Warfare, trans. Samuel B. Griffith (Courier Corporation, 2005).

Merrill, John, 'The Cheju-Do Rebellion', Journal of Korean Studies, 2 (1980), 139-97.

Metz, Steven, and Raymond Millen, Insurgency and Counterinsurgency in the 21st Century: Reconceptualizing Threat and Response (Carlisle, PA: Army War College, 2004).

Millett, Allan, The War for Korea, 1950-1951: They Came from the North (University Press of Kansas, 2010).

Millett, Allan, Williamson Murray, and Kenneth Watman, 'The Effectiveness of Military Organizations', International Security, 11/1 (1986), 37-71.

Moon, Changsong. 1995. Hallasaneun Algoitda: Mutyeojin 4.3ui Jinsang [Halla Mountain Witnessed: The Hidden Truth of the 4.3 Incident]. Jeju: Dealim.

Mueller, John, 'The Banality of "Ethnic War", International Security, 25/1 (2000), 42-70.

National Assembly Committee on Civilian Massacre, Investigative Report on Civilian Massacre, 4th National Assembly, 35th session, 1960.

Nagl, John, Learning to Eat Soup with a Knife: Counterinsurgency Lessons from Malaya and Vietnam (Chicago: The University of Chicago Press, 2005).

Olson, Mancur, 'Dictatorship, Democracy, and Development', American Political Science Review, 87/3 (1993), 567-76.

Paik, Sun-yup, Shilrok Chiri-san [The True Record of Chiri Mountain] (Seoul: Koryeo-won, 1992).

Paik, Sun-yup, From Pusan to Panmunjom (Washington, DC: Brassey's, 1992).

Pampinella, Stephen, 'The Effectiveness of Coercive and Persuasive Counterinsurgency Practices since 1945', Civil Wars, 17/4 (2015), 503-26.

Pan-National Committee for Civilian Massacres, Hangukjeonjaengjeonhu Minganinhaksal Siltaebogoseo [Fact-finding Report on Civilian Massacre Before and After the Korean War] (Paju: Hanul, 2005).

Park, Soul, 'The Unnecessary Uprising: Jeju Island Rebellion and South Korean Counterinsurgency Experience 1947-48', Small Wars and Insurgencies, 21/2 (2010), 359-81.

Park, Soul, and Seung Joon Paik, 'Command Coordination and Tactical Effectiveness in Counterinsurgency Operations: Lessons from the South Korean Campaign', Small Wars and Insurgencies, 29/2 (2018), 291-315.

Pollack, Kenneth, Arabs at War: Military Effectiveness, 1948-1991 (Lincoln: University of Nebraska Press, 2002).

Ramsey, Robert, Advising Indigenous Forces: American Advisors in Korea, Vietnam, and El Salvador (Fort Leavenworth, KS: Combat Studies Institute Press, 2006).

Reardon, Mark, 'Chasing a Chameleon: The US Army Counterinsurgency Experience in Korea, 19451952', in Richard Davis (ed.), The US Army and Irregular Warfare, 1775-2007 (Washington, DC: Center of Military History, 2008), 213-28.

Roh, Min-yong, and Hee-jung Kang, Geochang Yangminhagsal: Geu Ijhyeojin Piuleum [Geochang Incident: The Forgotten Bloody Tears] (Chung-ju: Onuri, 1988).

ROKA Headquarters, Gongbitobeolsa [History of Counterguerrilla Operations] (Seoul: ROKA Headquarters, 1954).

ROKA Headquarters (ed.), The Korean War Material Collection 59 (Seoul: ROKA Headquarters, 1988). 
Sawyer, Robert, Military Advisors in Korea: KMAG in Peace and War (Washington, DC: Center of Military History, 1988).

Steele, Abbey, 'Electing Displacement: Political Cleansing in Apartadó, Colombia', Journal of Conflict Resolution, 55/3 (2011), 423-45.

Steele, Abbey, Democracy and Displacement in Colombia's Civil War (Ithaca: Cornell University Press, 2017).

Strachan, Hew, 'Training, Morale and Modern War', Journal of Contemporary History, 41/2 (2006), 211-27.

Talmadge, Caitlin, The Dictator's Army: Battlefield Effectiveness in Authoritarian Regimes (Ithaca: Cornell University Press, 2015).

Thaler, Kai, 'Ideology and Violence in Civil Wars: Theory and Evidence from Mozambique and Angola', Civil Wars 14/4 (2012): 546-67.

The National Committee for Investigation of the Truth about the Jeju April 3 Incident (ed.), Jeju 4.3 Sageon Jaryojip 4: Jeongbu munseo pyeon [4.3 Incident Document Collection 4: Government Documents] (Seoul: National Committee, 2002).

The National Committee for Investigation of the Truth about the Jeju April 3 Incident (ed.), Jeju 4.3 Sageon Jaryojip 5: Gungyeong Jaryopyeon [4.3 Incident Document Collection 5: Military and Police Documents] (Seoul: National Committee, 2002).

The National Committee for Investigation of the Truth about the Jeju April 3 Incident (ed.), Jeju 4.3 Sageon Jaryojip 7: Migukjaryopyeon I [4.3 Incident Document Collection 7: U.S. Documents I] (Seoul: National Committee, 2002).

The National Committee for Investigation of the Truth about the Jeju April 3 Incident (ed.), Jeju 4.3 Sageon Jaryojip 8: Miguk Jaryopyeon II [4.3 Incident Document Collection 8: U.S. Documents II] (Seoul: National Committee, 2002).

The National Committee for Investigation of the Truth about the Jeju April 3 Incident (ed.), Jeju 4.3 Sageon Jaryojip 9: Miguk Jaryopyeon III [4.3 Incident Document Collection 9: U.S. Documents III] (Seoul: National Committee, 2002).

The National Committee for Investigation of the Truth about the Jeju April 3 Incident, Final Report of Investigation of Jeju April 3 Incident (Seoul: Sunim-sa, 2003).

Truth and Reconciliation Commission, Report for the First Half of 2007 (Seoul: TRC, 2007).

Truth and Reconciliation Commission, Report for the Second Half of 2008, vols. 2-3 (Seoul: TRC, 2008).

Truth and Reconciliation Commission, Report for the First Half of 2009, vol. 4 (Seoul: TRC, 2009).

Truth and Reconciliation Commission, Report for the Second Half of 2009, vol. 7 (Seoul: TRC, 2009).

Truth and Reconciliation Commission, Report for the First Half of 2010, vols. 3-5, 8 (Seoul: TRC, 2010).

Truth and Reconciliation Commission, Final Report III (Seoul: TRC, 2010).

Valentino, Benjamin, Paul Huth, and Dylan Balch-Lindsay, "Draining the Sea": Mass Killing and Guerrilla Warfare', International Organization, 58/2 (2004), 375-407.

Wood, Reed, 'Rebel Capability and Strategic Violence Against Civilians', Journal of Peace Research, 47/5 (2010), 601-14.

Yang, Yong Jo, 'Operationalization and Characteristics of North Korean Guerrilla during the Korean War', Bugaksaron [The Journal of Historical Studies], 10 (2003), 439-76.

Yoo, Chae-hung, Gyeokdongui Sewol [In the Time of Turbulence] (Seoul: Euljimunhwasa, 1994).

Zhukov, Yuri, 'Population Resettlement in War: Theory and Evidence from Soviet Archives', Journal of Conflict Resolution, 59/7 (2015), 1155-85. 